KATARZYNA STANKIEWICZ

University of Gdańsk

ANNA ŻUREK

University of Wrocław

\title{
Interculturality on the border of disciplines. Polish language teaching as a means of intercultural education*
}

\begin{abstract}
The goal of the article is a presentation of the existing and potential relations between Polish language teaching and intercultural education both in the theoretical and practical aspect. The authors present the basic assumptions and goals of intercultural education, paying particular attention to intercultural learning. What follows is a thorough analysis of the presence of the intercultural approach in the theory and practice of the Polish language didactics and its relation to the pedagogy.
\end{abstract}

KEYWORDS: Polish language teaching, Polish as a foreign language, intercultural education, intercultural learning, intercultural competence.

\section{INTRODUCTION}

The purpose of our article is to show the potential and actual relationships between Polish language education and intercultural education, functioning in Polish pedagogical discourse. These relationships were analyzed at both the theoretical and practical levels. We outlined briefly the objectives and goals of multicultural education, with particular emphasis placed on the process of intercultural learning, and then we analysed the presence of intercultural approach in the theory and practice of teaching and its relation to the pedagogues' findings. The language games aimed at the development of

* Scientific work funded by the Polish MNiSW in 2008-2013 (Research project No. N N106 331834). 
learners' intercultural competence are an example of applying intercultural education tools in teaching Polish as a foreign language. Therefore we presented exercises aimed at multicultural groups at intermediate and advanced levels of language acquisition, where it is possible to develop all language skills during the process of intercultural learning.

In the literature on the subject, language education, language education (glottodidactics) is understood as an independent academic discipline focused on the process of learning and teaching a foreign language (Komorowska 1983: 33). It is a relatively new discipline developed on the border between different sciences where their research methodology is used. The teachers and pedagogues consider glottodidactics, which is also referred to as a foreign language education, as a teaching sub-discipline with a long tradition (Szulc 1997: 53). Like other specific field teaching methodologies, it sets goals, determines content, principles, methods and forms of teaching a foreign language and explores the psychological and social conditions of the process. As such, it provides the basis for teaching any languages as foreign languages, including Polish. On the one hand, as the name itself suggests, there is a close relationship of the discipline with pedagogy (Szulc 1997: 53), on the other hand there is a clear line between glottodidactics and other disciplines, particularly pedagogy, and there is a strong tendency to become an independent discipline (Komorowska 1982: 33).

\section{FROM MULTI- TO INTERCULTURAL EDUCATION}

The relationship between teaching Polish as a foreign language and pedagogy is particularly interesting; more specifically the relationship between teaching Polish as a foreign language and intercultural education and - more generally - the intercultural pedagogy. The latter being in Poland a new pedagogical sub-discipline, where language education in cultural diversity groups is a focal point. The autonomy of intercultural pedagogy as a sub-discipline - is still a matter of debates and controversy in the circles of Polish pedagogues (Jasiński 2004: 85-95; Grzybowski 2008: 102), and therefore this article refers primarily to the multicultural education as an important area of a pedagogical practice, becoming also an object of scientific reflection.

Intercultural education can be understood in two ways, as:

- an educational practice in a multicultural society (this definition gives a fairly narrow meaning);

- a new idea, affecting the shape of the overall education and organizing contemporary approach to education and training - broad approach to this issue (Lewowicki 2000: 31; Jasiński 2004: 85-95). 
In the language education context, it would be appropriate to recognise intercultural education as a kind of idea, which could have a significant impact on teaching a foreign language at the level of its objectives and educational content. It is worth pointing out, that in the face of the growing cultural diversity of societies and the ever increasing contacts of different cultures and nations representatives, in the era of globalization and European integration, the idea of intercultural education becomes the idea of education in general which organises a common educational practice (Nikitorowicz 2005: 43), including language education (Zawadzka 2004: 185-191; Bandura 2007: 57-68).

Intercultural education, understood as a particular model of educational activities, is preceded by a model based on slightly different assumptions, often referred to as multicultural education. In the subject matter literature we find a description of the transition from one model to the other, which can be associated with the "postmodern breakthrough" (Lewowicki 2000: 31). However, this approach is too simplistic, because in many areas of educational practice we still have to deal with elements of a multicultural approach, while apart from the postmodern thought, we can point out other important reasons for educational changes, such as the socio-political and economic changes.

These models are fundamentally different in their approach to minority groups and to the various representatives of different cultures. The primary objective of multicultural education is "to protect the interests of the dominant group"; differences or deviations from the "cultural norms" are treated as a "lack of" which may be made up in the course of training conducted in line with standards generally accepted by the society (Lewowicki 2000: 31; Grzybowski 2008: 31).

Contrary to the multicultural model, intercultural education is directed at all members of a culturally diverse society, not limited to minority groups (Lewowicki 2000: 31). Such an approach is connected with the fact that differences are seen as values and treated as something that should not be alienated or reduced. This model is aimed at developing individual's and group's relationships with people from different cultures by respecting their otherness (Grzybowski 2008: 60-61).

The transition from the multicultural to intercultural model - so important to teachers - has not been generally recognized by teachers of Polish as a foreign language because of their limited interest in the pedagogical approach to multiculturalism. In language education, esp. when teaching English or German as a foreign language, the pedagogical approach is more appreciated which is reflected in the intercultural approach to teaching these languages (Bandura 2007). We believe that reconsidering the paradigm shift in education could have important implications for the teaching of Polish as 
a foreign language. Despite the lack of direct references, there are some parallels to that "breakthrough" in Polish language education which can be seen in the transformation of teachers' approaches to teaching culture in a language course (Miodunka 2006: 7-9; Gębal 2006: 205-242).

The intercultural education can be viewed from both an individual and a social group perspective. From an individual's perspective, the primary objective of educational activities is to develop intercultural competence in the process of intercultural learning, which is connected with the search and development of the individual's cultural identity (Nikitorowicz 2005: 45; Śliwerski 2005: 294-298). From the macrosociological perspective, this type of educational practice is to promote a social integration, deepen mutual tolerance among different cultural groups and enable interactions in their circles (Lewowicki 2000: 32).

The individual's perspective and the individual as a participant of the educational process is more interesting. Such an individual is a person for whom intercultural education creates opportunities for personal growth and better adaptation to the modern world. For language education the process of intercultural learning - often described in the literature on teaching which takes place in language courses, is extremely important. It occurs in situations of intercultural contact when one person meets another and both of them are focused on mutually understanding their beliefs or values while remaining aware of the specifics of their own culture. The aim of such teaching is to shed light on both one's own and a foreign culture, to build one's own cultural identity and to develop one's intercultural competence (Śliwerski 2005: 292; Grzybowski 2008: 38).

In the latter, we can distinguish the following aspects:

1. cognitive - pertaining to the knowledge of the culture, both one's own and the other/ foreign one;

2. emotional - defining certain attitude and behaviour toward a representative of another culture (such as tolerance, openness, curiosity);

3. behavioural (also referred to as pragmatic), which defines how an individual applies his own knowledge and attitude when in contact with another culture, for example when resolving potential or existing conflicts (Grzybowski 2008: 38).

\section{INTERCULTURALITY IN CULTURAL EDUCATION IN A POLISH LANGUAGE COURSE FOR FOREIGN STUDENTS}

The teachers of Polish as a foreign language whose are interested in the phenomenon of interculturality often fail to notice the achievements of Polish pedagogy, although this discipline abounds in potential references 
and opportunities of interdisciplinary cooperation. Interculturality tends to appear as a problematic issue when it comes to academic works in the scope of cultural education (Zarzycka 2000; Zarzycka 2004; Garncarek 2006; Gębal 2006).

The authors, when discussing intercultural competence, give it a slightly different meaning to the teachers and place it next to cultural (in the scope of Polish culture) and communication competence. In Polish language education, the concept of intercultural competence is often reduced to its cognitive and behavioural aspects, which are limited to describing the type of communication between individuals (Zarzycka 2008: 68-70).

In teaching Polish as a foreign language, a number of key approaches to cultural education can be distinguished, all arising in connection with experiences originating from teaching other languages (Gębal 2006: 205-242). The first factual approach focuses on the transmission of knowledge about Polish culture. It is strictly monocultural and closest to the multicultural education model. The second approach - communicative - is also oriented at monoculture (the Polish culture) and is focused on the behavioural aspect of communicative competence. The third intercultural approach is to develop all of these aspects of the intercultural competence model, and above all, is oriented towards the emotional aspect, which is the development of an individual's approaches and attitudes. An eclectic approach is also possible, combining elements of the others (Gębal 2006: 205-242).

In teaching Polish as a foreign language, all of these approaches are ever present, in particular the popular eclectic model. They evolved one by one, indicating the direction of changes in the treatment of the cultural component: from mono- to multi-, and even intercultural. It is worth pointing out that the reduction and replacement of ethnocentric content with sociocultural and intercultural content in teaching a foreign language is similar to the transition from multicultural to intercultural education; and like the transition from the approach aimed at assimilation to the promotion of cultural diversity.

\section{BETWEEN DISCIPLINES}

In the context of the foregoing, it is worth asking the question of de facto relationships of teaching Polish as a foreign language (Polish glottodidactics) and intercultural education. Although language methodologists reach for solutions from various disciplines touching the issue of interculturalism, and in particular for methods of teaching other languages, they tend not to notice the achievements of Polish pedagogy (Miodunka 2006: 7-9; Gębal 2008: 
84-86). As mentioned before, references to multicultural education appear in works of Polish language teaching methodologists who concentrate primarily on cultural education issues (Zarzycka 2000; Garncarek 2006; Gębal 2006; Zarzycka 2008).

Rather than refer directly to pedagogical trends, the authors often use the general concepts of intercultural communication such as "cultural differences" or "intercultural dialogue" (Kurtyka 2005: 83-95). Their interest in interculturalism issues seems to be rather limited. Most frequently they talk about cross-cultural approach to teaching culture and they focus on methodology and curriculum issues (Gębal 2006).

Consequently, in subject matter literature on language education, we rarely see references to the findings of pedagogues. Instead, there are references to works on intercultural communication, which are rather theoretical than normative. They lack references to didactic objectives and ways of making a transition from educational theory into educational practice, which is so relevant from the perspective of pedagogy (Mackiewicz 2005; Bandura 2007; Torenc 2007).

The studies show that in teaching Polish as a foreign language, the ethnocentric and mono-cultural approach to the transmission of cultural content is still the dominant element, which means not reaching for a chance to meet with the "others" (representatives of different cultures), a chance which is created in the context of teaching Polish to an international group, not to mention the active development of students' sensitivity and intercultural competence (Stankiewicz 2009).

Although the terminology used in teaching Polish as a foreign language and pedagogy is often similar to each other, one can see a twist of meaning in them when it comes to certain concepts (Zarzycka 2008: 63-77). It happens that new terms are created in language teaching while their equivalents have long been present in Polish pedagogy. The previously mentioned concept of intercultural competence has gained in importance recently and it is used in both the disciplines. However, Polish language teachers look at it primarily from the perspective of communication studies, which differs from the understanding proposed by pedagogues. In teaching Polish as a foreign language the concept of interculturalism and other derivative terms into the realm of language and communication are sometimes narrowed by neglecting considerations of educational objectives in a wider social context.

In the context of these observations, it seems necessary to broaden the operations on the boundaries between these two disciplines through developing glottodidactic reflection of the desired objectives and educational content supported by pedagogical findings and then linking them with overall methodology of teaching, developing attitudes of learners studying Polish as 
a foreign language in language courses as well as transmitting certain values and approaches to other cultures. Consideration of the cultural message and the image of Polish culture presented in learning materials for teaching Polish as a foreign language is important, but even more is the educational practice resulting from adopting a particular approach to the presentation of Polish culture and other cultures in the Polish language classes for foreigners.

\section{TOWARDS TEACHING}

Intercultural contents are very attractive from the perspective of a learner who studies Polish as a foreign language, and they can be integrated into a language course (Stankiewicz, Żurek 2009: 196-212). This is in line with European guidelines regarding foreign languages teaching methodology, outlined in the Common European Framework of Reference for Languages: Learning, Teaching, Assessment (2003).

The purpose of this article - besides purely theoretical considerations - is also to present ways of combining elements of intercultural education with the methodology of teaching Polish as a foreign language, especially as far as the teaching of foreign students studying in multicultural groups is concerned. A development of all language skills in the framework of intercultural learning seems particularly interesting. In conclusion we present examples of exercises where all aspects of intercultural competence can be included in a classroom context. They reflect the intercultural approach to teaching Polish as a foreign language and are based on the principles of intercultural education (Stankiewicz, Żurek 2009: 196-212).

The first example is the game entitled Every country has its customs intended for advanced students of Polish (at B2/C1 level). Developing intercultural competence involves learning about different customs and developing students' cultural and national identity. The language learning objective focuses on practising vocabulary related to everyday objects, customs and rituals of the considered culture. What is important from the perspective of educational practice is the fact that the number of participants of the game is undefined. Students decide which subjects and materials to use. They form groups consisting of representatives of one culture and prepare a presentation on common customs and behaviours Then they present objects which they consider important in their culture in the form of a multimedia presentation, a short play, etc. Such presentations take place regularly e.g. every two weeks (Losche 2003: 148).

Another exercise is called Who am I? and it includes defining one's identity; presenting typical elements, and defining differences between one's 
own perception of oneself and the way one is perceived by others. It can also be used as a starting point for discussion on similarities and differences in cultures. Language context includes terms referring to family members, types of relationships, affinity and naming interpersonal relations. Like in the game described before, the number of participants is not defined here either. However it is best if the number is even as students are supposed to work in pairs. The teacher explains the rules. Each student has to fill in their own worksheet with features that are important to him/herself and a similar worksheet about his/her partner. First, everyone fills in worksheets individually. They assess importance of the features (such as nationality, name, character, etc.) by placing them in circles of numbers where number 1 means the most important feature. Then students compare their results in pairs and discuss similarities and differences in perceptions After a while there is time for a group discussion moderated by the teacher during which students discuss similarities and differences in defining identity and how they depend on the respondent's selection of the place in the hierarchy of importance s/ he assigns to nationality (Brander 1995: 29-30).

\section{CONCLUSION}

A Polish language course for foreigners provides an opportunity to broaden their knowledge of the language and also helps them adapt to a different cultural reality. At the same time it functions as a space where different cultures can meet (Stankiewicz, Żurek 2009: 196-212). It creates a convenient basis for starting an intercultural education. To implement this educational model, teaching Polish as a foreign language should take place not from the position of a dominant culture, but should focus on intercultural dialogue, based on an intercultural learning process. This requires giving up the ethnocentric position where Polish culture is placed in the centre and implementing cultural relativism which assumes that all cultures and cultural contexts are equal and which is open to the "other" and his/her views.

The effect of such a teaching method will be a growth in students' language competence supported by socio-cultural knowledge about Poland, and supplemented by a cross-cultural competence which enables them to find themselves in a culture that is foreign to them, reach for opportunities arising from contacts with what is foreign and different, and use it in the process of developing their own identity. After adopting such objectives, a language course becomes a meeting place with cultures (and not just a meeting place with the Polish culture), and the teacher plays the role of 
cultural mediator. Pedagogy, in particular intercultural education, poses new challenges for the methodology of teaching Polish as a foreign language which go far beyond the methodological and curriculum issues and at the same time enhance the status of this area of education.

\section{REFERENCES}

Bandura, E., 2007. Nauczyciel jako mediator kulturowy. Kraków: Wydawnictwo Tertium.

Brander, P., 1995. All different - All equal, Education pack. Strasbourg: Komisja Europejska.

Europejski System Opisu Kształcenia Językowego: uczenie się, nauczanie i ocenianie, 2003. Warszawa: Rada Europy.

Garncarek, P., 2006. Przestrzeń kulturowa w nauczaniu języka polskiego jako obcego. Warszawa: Wydawnictwo Uniwersytetu Warszawskiego.

Gębal, P., 2006. Realia i kultura w nauczaniu języka polskiego jako obcego. In: Lipińska, E., Seretny, A. (eds). Z zagadnień dydaktyki języka polskiego jako obcego. Kraków: Wydawnictwo Universitas, 205-242.

Gębal, P., 2008. W stronę podstaw dydaktyki języka polskiego jako obcego. Próba bilansu polonistycznej myśli glottodydaktycznej. In: Miodunka, W., Seretny, A. (eds). W poszukiwaniu nowych rozwiązań. Dydaktyka języka polskiego jako obcego u progu XXI wieku. Kraków: Wydawnictwo Uniwersytetu Jagiellońskiego, 79-88.

Grzybowski, P., 2008. Edukacja międzykulturowa - przewodnik. Pojęcia, literatura, adresy. Kraków: Oficyna Wydawnicza Impuls.

Jasiński, Z., 2004. Od pedagogiki narodowej do pedagogiki międzykulturowej. Refleksje na progu eurointegracji. In: Paszko, A. (ed.). Edukacja międzykulturowa w Polsce na przełomie XX i XXI wieku. Kraków: Wojewódzka Biblioteka Publiczna.

Komorowska, H., 1982. Metody badań empirycznych $w$ glottodydaktyce. Warszawa: Wydawnictwo Naukowe PWN.

Kurtyka, A., 2005. Rozwijanie kompetencji międzykulturowej nauczycieli języków obcych. In: Mackiewicz, M. (ed.). Dydaktyka języków obcych a kompetencja kulturowa i komunikacja interkulturowa. Poznań: Wydawnictwo Wyższej Szkoły Bankowej, 83-95.

Lewowicki, T., 2000. W poszukiwaniu modelu edukacji międzykulturowej. In: Lewowicki, T. (ed.). Edukacja międzykulturowa w Polsce $i$ na świecie. Katowice: Wydawnictwo Uniwersytetu Śląskiego, 21-35.

Losche, H., 2003. Interkulturelle Kommunikation. Sammlung praktischer Spiele und Übungen. Augsburg: Ziel.

Mackiewicz, M. (ed.), 2005. Dydaktyka języków obcych a kompetencja kulturowa i komunikacja interkulturowa. Poznań: Wydawnictwo Wyższej Szkoły Bankowej.

Miodunka, W., 2006. Wprowadzenie. Metodyka, dydaktyka, pedagogika a nauczanie języka polskiego jako obcego. In: Seretny, A., Lipińska, E. (eds). Z zagadnień dydaktyki języka polskiego jako obcego. Kraków: Wydawnictwo Universitas, 7-9.

Nikitorowicz, J., 2005. Edukacja międzykulturowa. Kreowanie tożsamości dziecka. Gdańsk: Gdańskie Wydawnictwo Psychologiczne.

Stankiewicz, K., 2009. Jawny i ukryty przekaz kulturowy w nauczaniu języka polskiego jako obcego. Unpublished doctoral dissertation mentored by prof. Z. Kwieciński, Toruń: Wydawnictwo Uniwersytetu Mikołaja Kopernika. 
Stankiewicz, K., Żurek, A., 2009. Polish Language Course as a Place to Meet Different Cultures: Integration of Language Skills Development with Intercultural Learning. In: Czerka E., Mechlińska-Pauli, M. (eds). Teaching and learning in different cultures. Gdańsk: Wydawnictwo Gdańskiej Wyższej Szkoły Humanistycznej, 196-212.

Szulc, A., 1997. Stownik dydaktyki języków obcych. Warszawa: Wydawnictwo Naukowe PWN.

Śliwerski, B., 2005. Wspótczesne teorie i nurty wychowania. Kraków: Oficyna Wydawnicza Impuls.

Torenc, M., 2007. Nauczanie międzykulturowe - implikacje glottodydaktyczne. Wrocław: Oficyna Wydawnicza Atut.

Zarzycka, G., 2000. Dialog międzykulturowy. Teoria oraz opis komunikowania się cudzoziemców przyswajających język polski. In: Acta Universitatis Lodziensis, Kształcenie Polonistyczne Cudzoziemców, nr 11.

Zarzycka, G., 2004. Linguakultura - czym jest, jak ją badać i otwierać? In: Dąbrowska, A. (ed.). Wrocławska dyskusja o jezzyku polskim jako obcym. Wrocław: Wydawnictwo Wrocławskiego Towarzystwa Naukowego, 435-445.

Zarzycka, G., 2008. Opis pedagogiki zorientowanej na rozwój kompetencji i wrażliwości interkulturowej. In: Miodunka, W., Seretny, A. (eds). W poszukiwaniu nowych rozwiazań. Dydaktyka jezzyka polskiego jako obcego u progu XXI wieku. Kraków: Wydawnictwo Uniwersytetu Jagiellońskiego, 66-77.

Zawadzka, E., 2004. Nauczyciele języków obcych w dobie przemian. Kraków: Oficyna Wydawnicza Impuls. 